\title{
Impact of Covid-19 Pandemic on Agrifood System and Global Value Chains (GVCs); Perception of China and the World
}

\author{
Bornwell Mutale* Li Xianbao \\ College of Management, Ocean University of China, 238 Songling Road, Laoshan District, Qingdao-China \\ * E-mail of the corresponding author: bornwellmut1@gmail.com
}

\begin{abstract}
Covid-19 is a global public health catastrophe with repercussions for all facets of life. This paper reviewed the impact of Covid-19 on the Agrifood System and Global Value Chains (GVCs) with respect to China and the world. Literature from Peer-reviewed articles, trending news and related authentic online reports was objectively gathered and used in this review. China has been playing a substantial role as both a supply and demand nucleus in traditional trade and simple Agrifood GVC networks. However, the review established that Covid-19 has had a substantial impact on the overall GVCs and the Agrifood system of both China and the world. While the impact on China was obvious through the decline in GDP growth rate in 2020, the decline in Agrifood annual growth and the rampant job losses in the Agrifood sector, its overall economy has been less affected relative to the global economy. This is essentially owing to the Chinese vigorous and effective counter-measures to control the outbreak and ensure food security and economic resilience. We, therefore, concluded that the world should emulate China's Covid-19 counter-measures. Additionally, determinations to abate the disruption of Covid-19 on GVCs and encourage Agrifood trade can engender both short- and long-term paybacks.
\end{abstract}

Keywords: Covid-19, GVCs, Agrifood System, Agriculture, Trade, Economy, China, World

DOI: $10.7176 / \mathrm{JESD} / 12-10-09$

Publication date:May $31^{\text {st }} 2021$

\section{Introduction}

The Covid-19 pandemic embodies an unparalleled turmoil to the global economy as well as international trade, as production and consumption are reduced throughout the world. Trade and markets have always been pivotal to the development process of the world. For instance, in the Agrifood System, Dodds et al. (2014), asserted that markets increase consumers' choices and generate motivations for growers. Thus, permitting the ideal distribution of resources and offering the opportunities which connect the Agrifood System with other segments of the economy. This makes markets crucial for the structural transformation of the economy. The world has put up programs to achieve within a specific period in ensuring a hunger-free, healthy, economic and environmentally sound world. The most recent is the 2030 agenda containing 17 separate objectives called Sustainable Development Goals (SDGs), which are aimed at a better and sustainable future for all (FAO 2020). Principal to this agenda is the Agrifood sector because its main theme is to address world challenges such as eliminating hunger and poverty. Therefore, the Agenda 2030 integrates the whole package of sustainable development, namely, environmental, social and economic development with related objectives. The relationship of agriculture with food security, economic growth, employment and poverty alleviation, as well as nutrition and health are reproduced in most of the SDGs. These relations are perfectly identified by markets, both domestically and internationally. Hence the importance of well-performing markets in the whole process of motivating economic development.

Like the 2008 global financial catastrophe and the subsequent economic strike which delayed the progression of Agrifood GVCs, the Covid-19 pandemic is also likely to disturb the potential of Agrifood GVCs in global trade even further (FAO 2020). GVCs uphold trade linkages that act as networks of technology and knowledge diffusion during periods of economic growth; likewise, GVCs can convey economic shocks and their effects. Thus, as companies address the trade-off concerning effectiveness and flexibility to the economic strike, they may follow a course of localization of food production by reshoring actions for foods that allow it. These kinds of strategies might considerably undermine adeptness advances that are connected with relative advantage and could upsurge domestic food costs, which are uninvited especially when people's income is falling. 
Therefore, dependence on the Agrifood System from domestic and numerous sources throughout the world is a means of pliability against food uncertainty and economic depressions. Trade offers an effective avenue to better manage threats arising from a shock and to increase pliability. Thus, trade within GVCs has brought many benefits by permitting nations to source their inputs more resourcefully, to access information and capital outside the local economy and to broaden their activities into new markets (OECD 2013). Besides, (World Bank 2019) affirms that GVCs have played a crucial role in reducing poverty and offering a chance to third-world countries to advance and catch up with developed countries. One of the most effective means of addressing global crises is engaging in timely and accurate information dissemination. This is so because an informed community is well placed to make comprehensive judgements.

This paper aims to review the impact of Covid-19 on the Agrifood System and GVCs with reference to China and the World, then draw lessons thus far and provide policy recommendations accordingly. The rest of the paper is organized as follows; the next section presents the rationale and significance of the study followed by a synopsis of how to measure GVCs in section 3. Section 4 presents the detailed description of the Data source and study approach while section 5 presents the results and discussion. Implications, some lessons from China to other governments including policy recommendations about best counter-measure practices are presented in section 6 . Finally, section 7 provides the conclusion of the study and prospects.

\section{The Rationale and significance of the study}

The fundamental problem is that Covid-19 is a global phenomenon with the potential to completely interrupt local and global environmental, social as well as economic programs. Nations are contingent on each other for essential ingredients, pesticides, fertilizers, animal feed and human resource (Torero 2020). According to (World Bank 2020), Covid-19 brought a huge shock to the global economy and led to the deepest global recession since World War II. This has by far exceeded the 2008/2009 recession that was triggered by the global financial crunch. The Agrifood System and Trade within the GVCs are likely to be impacted. In the recent past, international trade in the Agrifood sector has performed extremely well although its overall growth rate has been slower since the 2008 global financial crisis. Third-world and emerging economies are gradually partaking in international markets, and their exports performance in the Agrifood trade is overwhelming. For this reason, not only have GVCs become an essential part of the Agrifood trade but much more a contributing factor to global and domestic economic development. GVCs refers to the increasing disintegration of the production of goods and services with valueadded in different countries in the productive cycle (UNCTAD 2015). The concept of GVCs can thus be understood as an evolution in the context of global supply chains management. They unbundle the production procedures into phases in different nations to accomplish efficiency gains (Baldwin 2012). In Agriculture, GVCs permits farmers and agri-businesses to overcome constraints that come as a result of not having a strong and exportorientated local Agrifood System. Although through GVCs nations have more options to be part of the global markets and can well influence their comparative advantage at any phase of the value chain they choose, GVCs are still underutilized.

According to (FAO 2020), on average, a 10\% upsurge in agriculture's GVCs participation can culminate in an increase of about $1.2 \%$ in labour efficiency within a short period. This instantaneous impact also decodes into continued lasting efficiency effects, which can bring about significant economic gains especially to developing nations. Thus, if meticulously synchronized, GVCs can enhance the effects of global trade on growth, technology and knowledge spillovers that can increase productivity, improve employment opportunities and raise people's income (HLPE 2020). Though GVCs may not automatically end in improved management of natural resources, GVCs are coherent with sustainable development objectives. Therefore, an active effort needs to be made to add sustainability to trade and promote GVCs, for instance, reducing or eliminating trade barriers, especially for developing countries. It is common knowledge that import tariffs are already high in many countries across the world and the advent of Covid-19 just seemed to have worsened the situation. Therefore, lowering these tariffs along GVCs in the face of the Covid-19 pandemic may help upsurge imports of inputs and intermediate products which are essential. This, in turn, can motivate production and exports, ensuing in considerable gains in productivity, employment and incomes. Before the advent of the Covid-19 pandemic, opening international markets and upholding GVCs would generate indispensable spill-over effects by transmitting skill and knowledge even in the Agrifood industry. However, converting these into long-term benefits needs corresponding tactics that can underpin competitiveness, namely, actions that will enhance governance and infrastructure, upgrade skills, and remove rigidities from the Agrifood System. Furthermore, regional trade treaties can as well be influential in encouraging GVCs while lower tariffs among parties can uphold upright synchronization and Agrifood Value 
Chains. Therefore, the attention of several economic sectors by such treaties may underpin their impact on Agrifood GVCs, as a noteworthy segment of Agrifood exports' value originates from other sectors besides food or agriculture. For instance, approximately $40 \%$ of the global value-added in food exports comes from imported services (FAO 2020).

Since the advent of the Covid-19 pandemic, several studies have been conducted in line with trade and GVCs, food and agriculture as well as the impact of Covid-19 on different sectors of the economy both in China and globally using different approaches. Such studies include for instance; "How Covid-19 changed our food systems and food security paradigms (Bakalis et al. 2020)"; "The socio-economic implications of the coronavirus pandemic (COVID-19) (Nicola et al. 2020)"; "Mapping global value chain (GVC) participation, positioning and vertical specialization in agriculture and food (Nenci 2020)"; "Global supply chains in the pandemic (Bonadio eta $l$. 2020)"; "Impact of Covid-19 on Food Security and Nutrition (HLPE 2020)"; "Policy Responses to Covid-19 and international trade (OECD 2020c)"; "Impact of Covid-19 on China's macroeconomy and Agrifood System (Zhang et al. 2020)" etc. However, no particular study has so far been done to specifically review the impact of the Covid19 pandemic on GVCs and the Agrifood System with respect to China and the world. China is the key global Agrifood country, suggesting that if the outbreak affects China, there would be a serious impact on the global Agrifood economy as well. This also entails a huge impact on the long-standing plan instituted by the Chinese regime and its opening-up policy (Iam et al. 2013). According to the Chinese Ministry of Agriculture (MOA 2020), since 1978, China has carried out a reform policy and a step-by-step opening-up process that has accelerated the pace of agricultural reform and development. Specifically, in the recent past, the Chinese government has prioritized agricultural work, rural areas, and farmers by implementing a series of public policies. Covid-19, however, has the potential to frustrate the Chinese objective in the Agrifood System and hence the World economy. It is against this backdrop that this paper endeavoured to review the impact that Covid-19 has had/will have on China and World's Agrifood System and GVCs.

\section{A synopsis of how to Measure GVCs}

According to the assertion by (Hummels et al. 2001), GVCs are the series of stages of production of a commodity or service that incorporate at least two international borders. Therefore, trade-in value-added data can be used to measure how a particular country or a sector is involved in the GVCs. Dellink (2020) argued that recognizing the source of the value-added entrenched in trade flows entails that both domestic and foreign value-added are combined to produce goods and services that are exported. These may later be embodied in other products or consumed as final goods and services. Furthermore, if imported inputs are embedded in exports, these inputs cross borders twice and thus are double-counted in the usual measurement of international trade, that is, gross exports and gross imports. According to (Koopman et al. 2014), splitting gross exports into domestic value-added, foreign value-added and double-counted trade flows affords the basis for consistently and precisely scrutinizing the input of countries and sectors to global trade.

The specialization in GVCs makes it unique because vertical specialization reveals the increasing interconnectedness of production processes in a vertical trading chain that springs across various countries (Hummels et al. 2001). Vertical specialization is measured as the share of the value of imported inputs in total exports. It is equivalent to backward linkages in GVCs and signifies the level to which countries rely on imported efforts in their production of exported commodities. For instance, farmers in a particular country that produce rice for the international market may import fertilizers to boost productivity.

Besides backward linkages, there are Forward linkages in GVCs. These reveal the degree to which exported commodities are used later in the value chain to be further exported to a third country. They are measured as the value of intermediate exports sent indirectly through third countries to the ultimate country.

Therefore, GVC participation is calculated as the sum of backward and forward linkages (Koopman, eta l. 2014). If a sector in a country has many forward value chain linkages, it is said to be upstream, while a sector in a country with many backward linkages is called downstream. It is worth noting that more than two countries participate in GVCs, and vertically specialized as the parts of the production process of the final commodity are split, with each part interconnected. An example of the GVC participation in the Agrifood System could look like figure 1. 


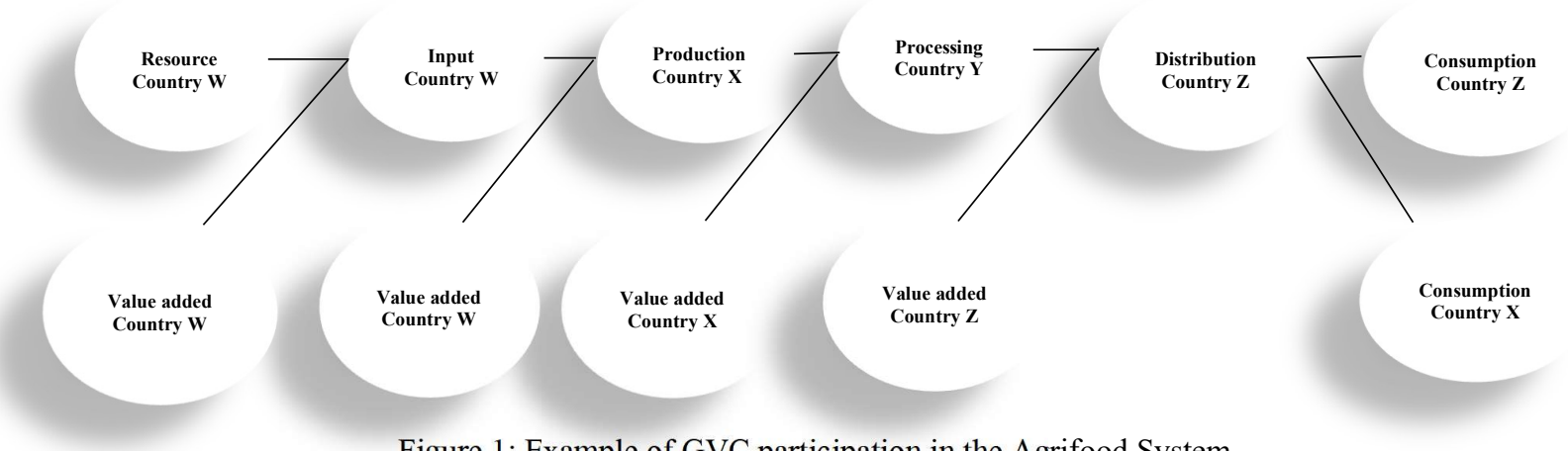

Figure 1: Example of GVC participation in the Agrifood System.

Source: Author's construction.

\section{Data source and Approach}

To accomplish the aim of this paper, a qualitative approach was utilized in which a comprehensive literature review was done on the topic at hand. Initiatives were taken to closely observe the trends of the pandemic as pertains to the Agrifood System and GVCs for China and the World. The methodology used was partly based on (Meyer 2020). Peer-reviewed articles were objectively collected from various authentic databases including; Google Scholar- https://scholar.google.com/, Science Direct-https://www.sciencedirect.com/, Scopus https://www.scopus.com/ and Web of Science - https://www.webofscience.com/. Furthermore, current and trending online news and reports from legitimate sources like the world bank, WTO, FAO, and OECD were utilized.

A comprehensive search protocol was followed using keyword combinations such as 'Covid-19+ World + Agrifood System' OR 'Covid-19 + Global Value Chains + World' OR 'Covid-19 + China + Agrifood System' OR Covid-19 + China + Agrifood Global Value Chains' OR 'Covid-19 + international trade'. Using this protocol, more than 2000 search results were found. However, upon refining the search further, 113 publications, considering their titles, were discovered to have been associated with the current topic. These were subjected to further filtering by carefully reading their abstracts and conclusions to discover those publications related to the present study as close as possible and maintain the aim of the study. After this exercise, only fewer than 100 publications, online reports, and conference documents were found to be particularly relevant to the current study. These were then adopted and used in this study. Figure 2 provides the graphical representation of this procedure. 
Major data sources

1. Google Scholar

2. Science direct

3. Scopus

4. Web of science

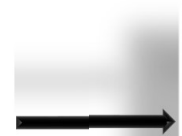

Other sources

1. World bank

2. WTO

3. FAO

4. OECD .

5. WHO
Keyword Combinations.

'Covid-19 + World + Agrifood System' OR 'Covid-19 + Global Value Chains + World' OR 'Covid-19 + China + Agrifood System' OR Covid-19 + China + Agrifood Global Value Chains' OR 'Covid-19+ international trade'.

Resulted in more than 2000 search items
Number of adopted publications for the review-Less than 100

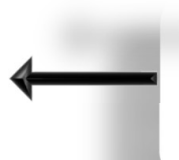

Number

Potential publications113

Further filtering.

Publication sort:

- Peer-reviewed

- Opinion papers

- International Organisations reports.

Publication content:

- Impact of Covid-19.

- Global value chain (GVC) and international trade;

- Agrifood System and

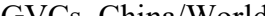

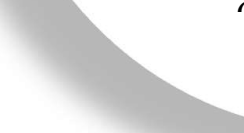

Figure 2. Methodological framework. Search protocol utilized to collect data for the review.

\section{Results and Discussion}

\subsection{How has Covid-19 Pandemic impacted Global Food Security and Trade?}

Since the World Health Organization declared Covid-19 as a global public health emergency on 11 March 2020 , (WHO 2020), several containment measures have been put in place. These include social distancing, minimizing group meetings and much more, border restrictions by countries. These measures have since been inevitably impacting all economic programs. Due to this, the World Trade Organization (WTO, 2020a) approximated global stock trade to drop by between $13 \%$ and $33 \%$ because of the disruption to economic programs. Figure 3 depicts trends in the world merchandise trade volumes from 2000 extending to 2022, and how it was estimated to fall in 2020 due to the pandemic. Similarly, according to data from the (OECD 2020a), the 2020 global economy was estimated to grow at a rate lower than 2.5\%. UNCTAD (2020) affirmed this by estimating the global GDP growth as shown in figure 4. 


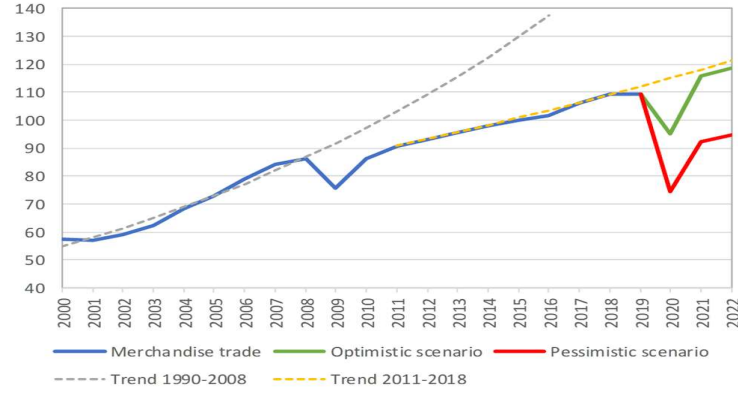

Figure 3. World merchandize trade volume, 2000-2022. Source: Adapted from WTO (2020).

Note: Figures for 2020 to 2022 are projections.

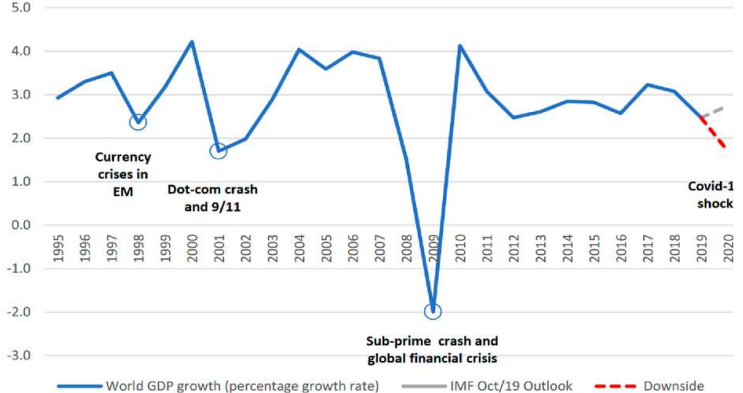

Figure 4. Global GDP growth, 1995-2020. Source: Adapted from UNCTAD (2020).

In the Agrifood sector, primary production, processing, trade, logistics and final demand are being affected by the pandemic. The spread of Covid-19 has huge consequences on both domestic and international food markets, income and employment, as well as food security and nutrition across the world. The measures that were put in place to respond to the pandemic, namely, social distancing and movement restrictions have the potential to negatively impact the work of farmers. These restrictions in turn can reduce Agrifood inventories locally and globally and may generate shortages in numerous important crops. According to (Nicola et al. 2020), social distancing on its own interrupted the availability, accessibility, utilization, and stability of food thereby implying a negative impact on people's diet (Jewell 2020). The restrictions on movement have been preventing farmers' access to markets to purchase inputs and sell their products. In most cases, fresh produce has been accumulating at farms, perishable products unable to timely reach the market, consequently resulting in food loss. Meanwhile, fright purchasing throughout the world has been causing further food wastage and upsetting the quality of diets as people struggle to access fresh food (Torero 2020). UNCTAD (2020) specified that the economic consequences of the pandemic are governmental issues of leadership and coordination. As such, the loss of consumer and stockholder confidence is the most instantaneous effects of the pandemic, while the devaluation of asset prices, weak collective demand, the upsurge in liability, and the deteriorating income disparity poses a greater danger to policy.

The Covid-19 pandemic brings out existing challenges in Agrifood Systems and emphasizes the need for enhanced pliability in food supply chains more broadly (FAO 2020a). The restriction on movement has also caused adverse impacts on the production and quality of food, on safety and impeded food distribution at every level of the value chain. The efficiency of the Agrifood organization is critical, particularly in times of crisis. According to (FAO 2020b), for labour-intensive crops, such as fruits and vegetables, movement restrictions could result in labour shortages, as border closures affected the availability of seasonal workers. Due to their perishable nature, fruits and vegetables are particularly susceptible to disruptions in the Agrifood Value Chain. Therefore, governments, for instance in China, introduced systems to provisional Agrifood workers, highlighting the difficulty of the sector to keep value chains operational. Likewise, in Europe, the movement was set up to link potential personnel and employers to maintain the supply of fruits and vegetables (https://pickforbritain.org.uk). Border closures also reduced the demand for a range of foods, pushing farmers and distributors into financial crisis. The impact due to restrictions of movement hits too much on developing countries where agriculture largely depends on labour as opposed to input dependent agricultural system of the developed countries. Consequently, value chains tend to be more fragile and susceptible to disruptions in developing countries compared to developed countries. The response measures are likely to further cause huge harvest decreases, increase food prices and heighten food insecurity. Although (FAO 2020b) estimated global cereal stocks to perform extra-ordinarily well and meet anticipated demand in the 2020-2021 season, the impact will still be remarkable because the future and extent of the pandemic are still ambiguous. Therefore, countries should facilitate the movement of workers and Agrifood products (Aday \& Aday 2020) while tracking every possible threat to the spread of the virus. Additionally, the impact on small scale farmers and/or vulnerable people needs to be cushioned financially. According to (Strange, 2020), the Covid19 pandemic has already exposed the weaknesses in GVCs in that, participants in the physical dissemination of goods may be at high risk of the virus, or may not be allowed to cross certain national borders. Thus, hindering 
the efficient and effective process of the GVCs. Furthermore, international air travel has been sternly constrained since March 2020.

The WTO very lately approximated the world merchandise trade capacity to plunge by $9.2 \%$ in 2020 . Subsequently, there would be an upsurge of about $7.2 \%$ in 2021, thereby leaving trade well below the average of its normal trend before the pandemic. However, this displays a less protracted drop in trade than originally predicted although substantial ambiguity remains about the robustness of the recovery henceforth. The second wave of Covid- 19 demanding new lockdowns measures could thus decrease the world GDP growth rate by $2 \%$ to $3 \%$ and cut off up to $4 \%$ merchandise trade growth rate in 2021 .

More to the impacts of reduced air and sea cargo are further challenges associated with the risk of food wastage through delays to handling difficulties, and the abrupt downfall in demand from restaurants and hotels. FAO (2020b) revealed that world food commodity prices had declined for consecutive 3 months in the first quarter of 2020. This was mainly due to the economic and logistical impacts of the pandemic resulting in significant contractions in demand for many commodities. However, despite the global logistic system picking up in the third and fourth quarter of 2020, the rates have persistently remained high as seen in figure 5 . These high rates are further putting more pressure on exporters, thus making the value chain even more disrupted especially with the resurgent of the second wave pandemic.

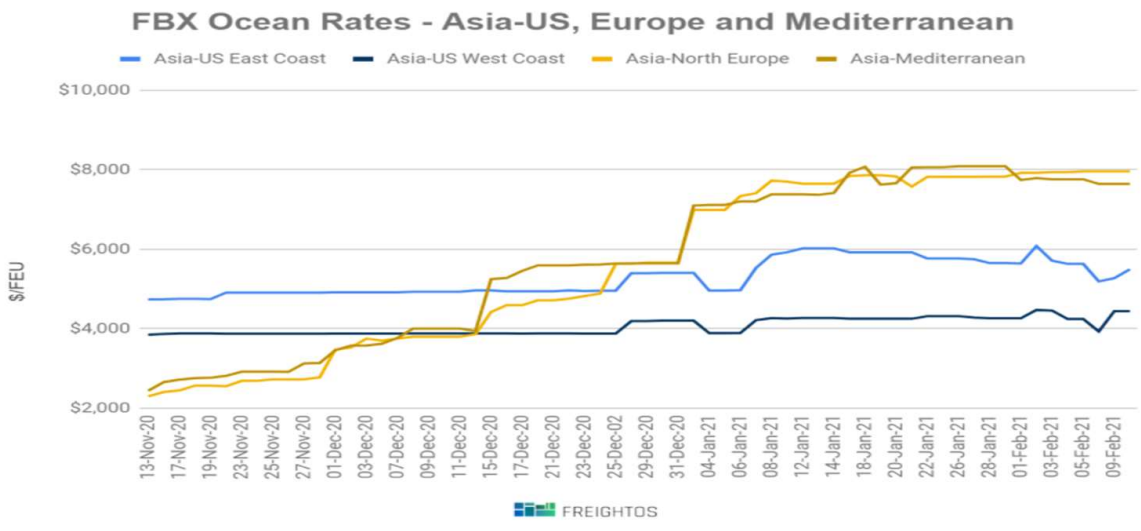

Figure 5. BFBX Ocean rates- Asia-USA, Europe and Mediterranean.

Source: FBX (2021). freightos.

Therefore, observing the international guidelines on safe travel and trade corridors can help keep Agrifood supply chains thriving, mitigate food supply disruptions and promote food security (OECD 2020c). While protecting and maintaining the health of Agrifood Supply Chain workers is vital during the outbreak (FAO \& WHO 2020), keeping the supply chain active by the supply management approaches is also imperative to meet the consumer demands (Lopes De Sousa Jabbour et al. 2020). This, therefore, calls for international partnership and coordination as opposed to movements that endorse autonomy in food, particularly when the pandemic impacts are varying in time and intensity across the world.

\subsection{How has Covid-19 impacted Food Access and Availability?}

According to HLPE (2020), the supply, demand and food access effects of Covid-19 are consistent with one another and affect food systems in various ways. Supply chain disruptions affect arrays of both supply and demand, while economic adversity affects food access which influences overall food demand as well as supply chain decisions. Therefore, as economic programs shrink, accessibility of food is anticipated to be negatively affected due to unemployment and income reductions. Such impacts have been immediate for people who work in sectors that are directly affected by social distance restrictions. However, individuals in the informal sectors are mainly susceptible to income losses. Although the demand for food is inelastic to income, there exist noticeable discrepancies across developed and developing countries, as well as within countries. Therefore, the degree of the impact of the pandemic on food access is mainly dependent on factors like the availability of household investments. However, the poor in society are impacted more negatively due to food insecurity. Thus, Aday \& 
Aday (2020) argued that during the pandemic, continuing the flow of the supply in the Agrifood sector, which is one of the most essential sectors together with health, is vital to prevent the food crisis and reducing the negative impact on the global economy. Hence, the supply chain should be flexible enough to respond to the challenges in the Agrifood System.

Furthermore, given the seasonality of agricultural production systems, most food producers, especially in developing nations, engage in non-farm and off-farm activities. They do this to support their livelihoods and equally raise capital for investments in their farms. Therefore, the reduction in the ability of farmworkers to travel to their occupation can further have direct implications on people's access to food, in the present and immediate future (FAO 2019). This may be due to deteriorations in income for capital investment to food security.

\subsection{Impact of Covid-19 on China's Agrifood System and Trade}

The Covid-19 pandemic mostly hit China's 2020 first and second quarter's economic growth. It was going to extend beyond this as well if the outbreak was not quickly controlled. However, the overall impact has had the potential to lower the Chinese real GDP growth rate in 2020 to approximately $5.4 \%$ and various economic researchers had even cut their forecasts for 2020 by 0.2 to 0.8 percentage points (HIS Markit 2020). According to information by the Chinese Ministry of Agriculture (MOA, 2020), China is currently the global leading producer of grains, fruits, vegetables, cotton, eggs, meat, fish and poultry products and has effectively resolved the challenge of feeding its rapidly increasing population which represents about a quarter of the world's total population. Because of this, (Zhan 2018) asserted that China continues to deepen supply-side structural reform in agriculture to develop the sector with the goals of increasing the production of superior products centred on green and innovative production practices. Thus, projecting the incorporation of new industries and new types of businesses (Man-Hung 2018). However, the arrival of Covid-19 has dared the economy of China and has even ignited trade conflict concerning the United States of America and the People's Republic of China. Sohrabi et al. (2020) further affirm that the Chinese regions responsible for over $90 \%$ of exports trade had either shut their production divisions or were operating at very low production capacity. While China embodies just a part of the world food production, the impact of Covid-19 has led to a series of containment measures with collateral effects globally. This can be seen for instance in (Blundell 2020) who reported changes in the dynamics of the consumption of goods in the United Kingdom that is affecting the supply and prices.

According to a study by (Zhang et al. 2020), Covid-19 significantly impacted China's macroeconomy and Agrifood Systems. China's GDP for instance plummeted by $6.8 \%$ during the early stages of the outbreak in 2020 compared with 2019 GDP around the same period. Like many sectors globally such as the manufacturing sector, the Agrifood sector in China has not been spared by the pandemic impact. It has been argued that although the economic injury of China's Agrifood sector during the peak of the pandemic in China was around $7 \%$ of its total value added which translates to nearly RMB 0.26 trillion, more than 46 million Chinese workers in the sector lost their employments due to the lockdown instigated by the Pandemic. This translates into approximately $27 \%$ of total jobs in the Agrifood sector of which the most affected are unskilled workers as opposed to their skilled counterparts (Zhang et al. 2020). According to (FAO 2020), China's labour crunches and logistics constraints had caused losses of fresh vegetables, limited access to animal feed and diminished capacity of slaughterhouses.

However, China being the first country to experience the impact of the Covid-19 outbreak was quick to put up vigorous counter-measures which saw the early suppression of the outbreak, thus, resumed its economic recovery especially during the third quarter of 2020. Even though the recovery in the value-added of the Agrifood System after vigorous counter-measures seemed encouraging, it has been modest. Several businesses resumed after the satisfactory control of the outbreak but the level of Agrifood System jobs was persistently lower than the threshold which can mainly be attributed to the slow recovery of restaurants as they play a vital role in employing in the sector. From the beginning of the lockdown, the drop in employment of the Agrifood sector amounted to approximately 8.6 million, translating into about $33 \%$ of the total jobs lost in China.

Additionally, the rapid spread of the outbreak in other parts of the world such as Africa and the second wave in the USA, India and several countries in Europe has a great impact on China's external demand despite having success in domestic control of the outbreak. Thus, making it hard to achieve full growth potential even under complete and normal economic operation. In 2019, China's Agrifood sector annual growth rate was estimated at $4.3 \%$. Conversely, the 2020 annual growth rate was relatively very low, with an estimation of $1.1 \%$ per year if export demands fully recommenced, and by $0.4 \%$ if export demands did not resume fully. This also has a 
significant impact on the whole economy in that the country's overall economy would grow by not more than $1 \%$ and about $1.7 \%$ in 2020 without resuming export demand and with export demand resumed respectively. In any case, the 2020 estimated rates are considerably lower than those of 2019 which were approximated at $6.1 \%$ annual GDP. The slow growth rate is likely to have a recurrent effect on 2021 growth and/or beyond depending on the future state or second wave of the pandemic in both China and the outside world.

China is an important agricultural export and import country in the GVC trade. Therefore, the impact of Covid-19 on China's Agrifood System is detrimental to the World. Figure 6 shows China's agricultural imports from the world and figure 7 represents China's exports of Agrifood commodities. These figures depict China's importance in global Agrifood trade.

China's Agricultural Imports from the World, 2001-2019

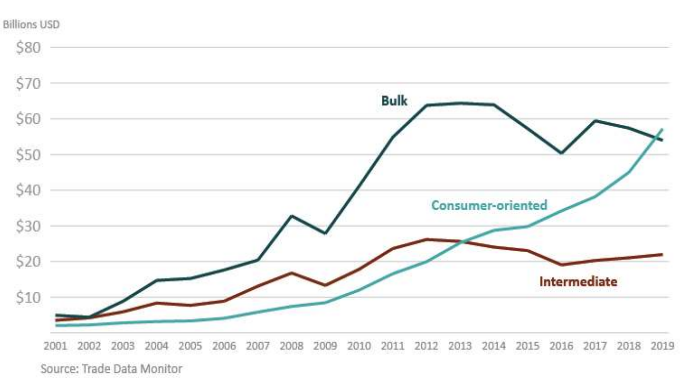

Figure 6. China's Agriculture imports from the world.

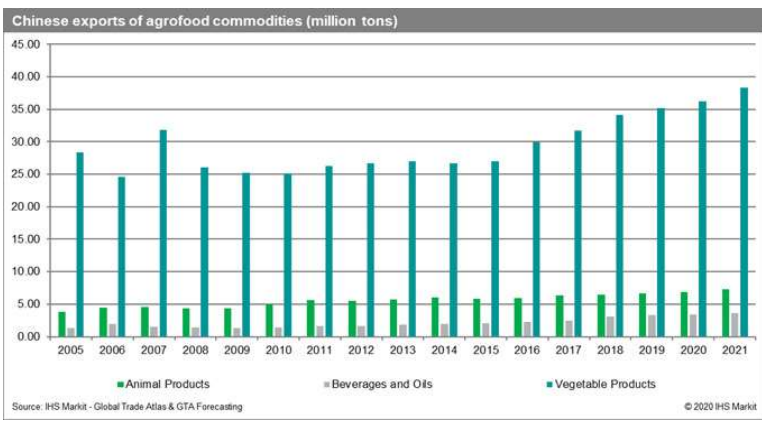

Figure 7. Chinese export of Agrifood commodities (Million tons)

\subsection{Submissions in promoting the safety of supply and economic recovery}

Covid-19 pandemic has had notably 3 phases, separated as Crisis, Recovery and New Normal Phase. Each phase is different from the other and needs explicit policy recommendations. While the crisis has already occurred, the important phase now is the Recovery and the New Normal or post-pandemic Phase. According to Govindan et al. (2020) argument, the recovery phase requires a reconsideration of the structure of a supply chain in terms of locality, production capacity and supervision of the flow of materials and data amongst the existing affiliates of the supply chain to identify advantages and disadvantages and ultimately to modify the supply chain structure. Table 2 presents some policy submissions for each phase. They entail what needs to be done with GVCs to promote the safety of Agrifood supply and economic recovery.

\section{Implications}

International trade is mainly motivated by population growth, changes in demography, technological development, Policy structure and increase in revenues. These in turn affect food supply and demand in various networks. This study asserts that unceasingly reducing economic reliance on exports and stimulating domestic demand are key areas that need attention. As the second wave of the pandemic is still serious in many parts of the world, its overall economic impact and the impact on GVCs and Agrifood System will depend on its duration and ultimate severity. The ultimate effect on the global economy will mainly depend on its geographic scope and the governments' counter-measures. The study has confirmed the earlier assertions about the emerging issues in the Agrifood supply chain since the beginning of Covid-19: The first issue is the assertion by (Rodríguez-Pérez et al. 2020) where it was argued that most people began to adopt a healthy diet to protect themselves from the virus. Thereby, increasing the demand for functional foods which comprise bioactive ingredients. The second issue is the anxiety for food security due to the lockdown restrictions while the third issue is the attention on food safety to prevent the transmission of the virus among producers, retailers, and consumers. The final issue is an assertion by (Galanakis 2020) who argued that food sustainability complications have arisen in the period of the Covid-19. Therefore, the Agrifood supply chain has so far faced remarkable challenges which need immediate and long-lasting yet stable interventions. While it has been argued that a few countries still have sufficient food provisions for the short term, 
it is projected (Deaton \& Deaton 2020) that the insecurity about food will increase in the long run especially in developing countries.

Table 2. What needs to be done to promote the safety of supply and economic recovery.

\begin{tabular}{|c|c|c|}
\hline Crisis phase & Recovery phase & New normal phase \\
\hline $\begin{array}{l}\text { 1. Maintain operations of } \\
\text { indispensable GVCs and } \\
\text { upsurge supply. }\end{array}$ & Assist to restart GVCs. & $\begin{array}{l}\text { Promote robustness and resilience in } \\
\text { GVCs. }\end{array}$ \\
\hline $\begin{array}{l}\text { 2. Expedite trade by removing } \\
\text { trade barriers and by ensuring } \\
\text { the smooth functioning of } \\
\text { international transport and } \\
\text { customs. }\end{array}$ & $\begin{array}{l}\text { Maintain an open trade and } \\
\text { investment environment to } \\
\text { reduce the time to recover and } \\
\text { continue to support trade } \\
\text { facilitation. }\end{array}$ & $\begin{array}{l}\text { Create a stable regulatory environment } \\
\text { through trade and investment agreements } \\
\text { that can include provisions for the smooth } \\
\text { operations of GVCs. }\end{array}$ \\
\hline $\begin{array}{l}\text { 3. Prioritize shipments for } \\
\text { essential goods and adopt rules } \\
\text { for the movement of key } \\
\text { personnel. }\end{array}$ & $\begin{array}{l}\text { Address financial and other } \\
\text { issues of firms that can delay } \\
\text { the recovery of GVCs and } \\
\text { support SMEs. }\end{array}$ & $\begin{array}{l}\text { Promote standards and certification } \\
\text { procedures including risk awareness; } \\
\text { review transport, logistics and customs } \\
\text { clearance regulations to better mitigate } \\
\text { disruptions. }\end{array}$ \\
\hline $\begin{array}{l}\text { 4. Increase the supply of essential } \\
\text { goods by facilitating } \\
\text { investment and operation } \\
\text { permits and by expediting } \\
\text { certification procedures. }\end{array}$ & $\begin{array}{l}\text { Adapt health measures to the } \\
\text { needs of firms operating in an } \\
\text { environment. }\end{array}$ & $\begin{array}{l}\text { Develop stress tests for critical supply } \\
\text { chains and include criteria for the } \\
\text { robustness of supply chains in } \\
\text { government procurement procedures on a } \\
\text { nondiscriminatory basis. }\end{array}$ \\
\hline
\end{tabular}

Source. Adapted from OECD (2020).

The Agrifood sector in China and the world is capable of upholding economy-wide growth and employ many people as it mainly comprises Small Medium Enterprises (SMEs). And so, lost Jobs due to the pandemic necessitates strategies that encourage entrepreneurial innovation in these SMEs. The study also settles that the pandemic is likely to re-ignite the long-standing discussions about the supply chain risks associated with international production and trade. Covid-19 has so far underlined both the strengths and weaknesses of GVCs, especially for the supply of indispensable products. However, there is no clue that countries would have performed better without GVCs, as government restrictions in response to the pandemic have also impacted the supply of domestic inputs. Historical knowledge suggests that trade within GVCs can be disrupted and play a role in the propagation of economic shocks across countries. However, they also aid countries to recover quickly. More resilient production networks can be attained through better risk management strategies, underscoring risk cognizance and greater transparency in GVCs and enhancing agility. Sourcing strategies may differ across activities depending on the level of acceptable risk. Thus, Governments can uphold determinations of businesses to construct more resilient GVCs by gathering and sharing data on potential concentration and bottlenecks upstream, by encouraging stress tests for indispensable supply chains and by forming a favourable supervisory atmosphere which is not a source of additional, policy-related uncertainty (OECD 2020b).

Governments' strategies to impose restrictions and closing of both the public and private sectors to control the pandemic has been increasing the unemployment levels. As a result, poverty, particularly in low-income areas increases. This is consistent with the estimations by the International Labour Organisation (ILO) who reported that the impact of the pandemic will lead to the rise in global unemployment of between 5.3 and 24.7 million, indicating the hurdle to sustain business operations especially for SMEs (ILO 2020). This mostly hit the poor in society who have little or no resources to adjust to job and incomes losses, the upsurge in food prices, the insecurity of food accessibility and availability. For this reason, regions that are presently struggling with other crises; social, economic and political, which have previously increased their food insecurity have found it very hard to respond to Covid-19 demands. The hurdle has been especially arising from the competition in resource allocation between the already existing food demands and the present health emergency. 
Although many food producers may still perceive the demand for their production, Covid-19 disruptions to Agrifood supply chains and markets are still likely to make their occupations insecure. This is more evident in countries with stringent rules that may have a negative influence on the overall Agrifood supply and demand. Whereas economic shocks are seldom the chief drivers of food predicaments, they, however, deteriorate the sternness of serious food insecurity, as well as protracting the duration of the disaster. The Covid-19 crisis has implications for this and already more than 96 million people in 33 countries who earlier experienced acute food insecurity lived in places where the economy was undergoing economic shocks of rising unemployment, currency depreciation and high food prices (OECD 2020a). Governments across the world will need to adapt to the new paradigm of effectively allocating resources between health needs and food security while maintaining Agrifood System trade. However, these shifts both in terms of addressing the pandemic and the broader economic fall-out will largely impact and compromise food availability and access both in the short and long run. Subsequently, people's nourishment is likely to be impacted due to the shift in diets to more inexpensive as well as more shelfstable and pre-packaged foods. Furthermore, the Agrifood System stability is compromised due to the instability and uncertainty of the markets. This increases disparities as people's capability to exercise agency over their connection with food systems is compromised. So then, the longer the control measures will remain, the more difficult the recovery phase might be for guaranteeing effortless food production, availability and international trade.

However, despite the quick spread and disruptive effects of the pandemic, China has been able to effectively control its spread and impact. The vigorous and effective response measures by the Chinese government to contain the virus is worth emulating by the world governments. The fact that China has managed to bring the outbreak under control has saved the world a great deal because the resources and attention which was to be directed to the world's most populated country are now being directed to the most vulnerable countries. These include countries in prolonged crises that lack proper public health facilities and have poor Agrifood Systems. China's strategic counter-measures that saw it control the outbreak and are worthy of learning by world governments are outlined in the following sub-section;

\subsection{China's Covid-19 counter-measures worthy of emulating by the world}

Since the reform and opening up of China, especially since the $18^{\text {th }}$ National Congress of the Communist Party of China, its food development and security have made great achievements which can be called a great miracle. The rural reform system and policy, agricultural operation subject and agricultural science and technology innovation provide strong support for the creation of national food development and security miracle. The coming of Covid19 has, however, dared China's industrial operations and farmers' employment through the global supply chain. Therefore, the counter-measures taken by China to face Covid-19 disruption are as follow:

1. Coordinate epidemic prevention and control measures and economic and social development systematic thinking design. The top-level system design of the emergency system should be improved, a dynamic and hierarchical response mechanism should be established, and an organizational structure for coordinated multi-departmental response and joint management should be formed;

2. Accelerate the resumption of work and production of SMEs, revitalize the cultural tourism industry, increase support for innovation and entrepreneurship and restore and stabilize farmers' employment and income;

3. Innovate the docking of agricultural products, implement industrial upgrading projects, improve risk management capabilities and stabilize and increase farmers' operational income;

4. Take the dual-track reform of supply and demand as the starting point to improve the "productioncirculation-consumption" trinity of food security to resolve the hidden risks;

5. Strengthen the domestic agricultural production support to ensure the supply of major agricultural commodities, actively respond to trade restrictions, effectively implement foreign agricultural aids and deepen international cooperation on food security;

6. Strengthen the research and judgement of international epidemics, take prompt precautions and stabilize the foundation for increasing farmers' income. Benchmarking issues, overcome difficulties and work systematically to help farmers increase their income through a package of policies and strive to achieve the goal of building a moderately prosperous society in all respect. 


\subsection{Post-Covid-19 Policy recommendations for China and the World}

In the post-Covid-19 era, new challenges have arisen in the world of Agrifood development and security pattern. Stable development of grain production and continued solution to the problem of eating well are top priorities of governing the country. Therefore, concerning the prospects of several major issues in the international agricultural corporation in China's $14^{\text {th }}$ Five-Year Plan; at the tactical level, space for optimal allocation of global agricultural resources is still large; at the strategical level, international agricultural cooperation requires more time resilience and more reasonable framework design. The international agricultural cooperation during the $14^{\text {th }}$ Five-Year-Plan not only need to solve specific real-world problems but also need to build a more systematic, flexible and open policy regime. Additionally, global cooperation needs to be strengthened, including ensuring the smooth flow of the food supply chain, keeping trade open, reducing the impact on agricultural production and focusing on the poor to prevent systemic risks of global and nutrition security.

China's overseas agricultural investment enterprises should turn the crisis into an opportunity to improve risk resistance and international competitiveness. This includes carrying out structural adjustment to form enterprise groups, conducting overseas M\&A to control global key industrial chains; the government should take measures to focus on the core objective of ensuring the important agricultural products supply, such as strengthening the top-level design, policy support, mechanism construction and public services, and promoting the coordinated integration of agricultural trade, investment and aid resources.

Governments will need to work together to strengthen their cooperation on global governance and implement policies and programs that target those most vulnerable. Trade channels should be kept open, for instance, China and the United States of America could abolish simulated trade tariffs to increase the flow of supplies of goods between the borders. E-commerce and delivery companies should be encouraged to play a key role to secure continued food access both domestically and internationally. Furthermore, there is a need to pay attention to the negative effects brought by the extension of the anti-epidemic campaign, actively dredge the supply channels of agricultural material, and orderly organize to return to the field and resume work.

Besides, governments should stabilize the policy support, improve the supporting facilities and equipment, strengthen the technical support for disaster prevention and mitigation. All countries should further strengthen bilateral consultations to stabilize the regional agricultural supply chain and should establish and improve coordination mechanisms for regional agricultural supply and early warming mechanisms for agricultural risks.

Further recommendations include the following:

- There is a need for governments to pay particular attention to the rivalry on resource allocations between the Agrifood System demands and Covid-19 demands when developing strategies to abate its impact. Furthermore, since the pandemic impact differs between countries, the settled strategies need to be rapid and responsive owing to the quick spread and evolutionary nature of the pandemic.

- There is a need for countries to enhance the local Agrifood Systems and trade than to entirely depend on GVCs. Therefore, future research should also concentrate on how this could be attained.

- Continuous research is needed to track the dynamic impact of the second wave of the Covid-19 pandemic on the global Agrifood System, GVCs and consistently device resilience measures against its negative impacts.

\section{Conclusion}

The Covid-19 pandemic has so far caused huge disruption to the global economy, Agrifood System and GVCs not as a virus in itself but mainly due to the measures put forth to control the spread thereof. The most notable measure has been social distancing which brought about the closure of financial markets, companies, international organisations and many other scheduled events. Additionally, the rate at which the pandemic has been spreading, and the intensified ambiguity about the deadliness of the virus has made economic players adopt security in consumption and investment. International trade known to stimulate economic growth and development has also been affected. Lately, the augmentation of GVCs has considerably altered the nature and organization of the global economy. Although the cumulative intricacy of GVCs carries inordinate challenges to policymakers, trading within GVCs particularly in the Agrifood System is very important for countries especially in times of crises, 
namely, the Covid-19 pandemic. China is currently a key player in traditional trade and simple GVCs activities such as the Agrifood trade as both an importer and exporter. Therefore, the impact of the Covid-19 pandemic on China's economy and its Agrifood System has the great potential to negatively impact the global economy. However, the initiative taken by the Chinese government to vigorously and effectively control the outbreak has saved China and lessened the economic impact at the global level. The major impact on China's economy and Agrifood industry was evident in the first and second quarter of 2020, though the external impact is still being felt due to border restrictions since most of her trade partners are still struggling with the outbreak. Therefore, essential commodity-exporting nations in GVCs need to make every effort to find solutions to abate logistic disruptions so that chief staple commodities can smoothly move across countries if the likely future economic impact of the pandemic is to be evaded. On the other hand, this pandemic is an opportunity to isolate the barriers in regional and international trade and address these barriers. Since border restrictions make international trade hard, there is a need for the logistics mechanisms of the supply chain to be appropriately tested and given exceptional authorizations to transfer commodities across countries in the face of the pandemic. Finally, the ultimate impact of Covid-19 on the global economy, Agrifood System and trade within the GVCs is yet to be fully quantified. However, world governments that are still struggling with the outbreak should learn from the Chinese countermeasures that saw the timely and effective control of the pandemic. These counter-measures will help abate the destructive effect of the second wave Covid-19 outbreak to the global economy, bring stability to international trade and the Agrifood System and save vulnerable countries from the increasing pressure of food insecurity and persistent poverty.

\section{Acknowledgement}

The authors are grateful to the anonymous reviewers for the review process.

\section{Funding}

This work did not receive any special funding.

\section{Conflict of interest}

The authors declare no conflicts of interest.

\section{References}

Aday, S., Aday, M.S. (2020). "Impact of COVID-19 on the food supply chain, Food Quality and Safety", Volume 4, Issue 4, Pages 167-180, https://doi.org/10.1093/fqsafe/fyaa024.

Bakalis, S., Valdramidis, V.P., Argyropoulos, D., et al. (2020). Perspectives from CO+RE: "How COVID-19 changed our food systems and food security paradigms", Current Research in Food Science, Volume 3, Pages 166172, https://doi.org/10.1016/j.crfs.2020.05.003.

Baldwin, R.E. (2020) Global Supply Chains: "Why They Emerged, Why They Matter, and Where They are Going". CEPR Discussion Paper No. DP9103, Available at SSRN: https://ssrn.com/abstract=2153484.

Blundell, R., Griffith, R., Levell, P., O’Connell, M., (2020). “Could COVID-19 Infect the Consumer Price Index?” Fisc. Stud. 2020, 41, 3574-360. https://doi.org/10.1111/1475-5890.12229.

Bonadio, B., Huo, Z., Levchenko, A.A., and Pandalai-Nayar, N. (2020). "Global supply chains in the pandemic", NBER Working Paper No. 27224. https://DOI10.3386/w27224.

Deaton, B.J. \& Deaton, B.J. (2020). "Food security and Canada's agricultural system challenged by Covid-19". Canadian Journal of Agricultural Economics/Revue canadienne d'agroeconomie, 68 pp. 143-149. https://doi.org/10.1111/cjag.12227.

Dellink, R., Dervisholli, E. \& Nenci, S. (2020). "A quantitative analysis of trends in agricultural and food global value chains (GVCs)". Background paper for The State of Agricultural Commodity Markets (SOCO). Rome, FAO. https://doi.org/10.4060/cb0729en. 
Dodds, R., Holmes, M., Arunsopha, V. et al. (2020). “Consumer Choice and Farmers' Markets”. JAgric Environ Ethics 27, 397-416 (2014). https://doi.org/10.1007/s10806-013-94694.

FAO and WHO (2020). "COVID-19 and Food Safety": Guidance for food businesses: Interim guidance Rome.https://doi.org/10.4060/ca8660en.

FAO. (2019). "The State of Food Security and Nutrition in the World". 2019, Rome, FAO. http://www.fao.org/state-of-food-security-nutrition.

FAO. (2020). The State of Agricultural Commodity Markets 2020. Agricultural markets and sustainable development: Global value chains, smallholder farmers and digital innovations. Rome, FAO. https://doi.org/10.4060/cb0665en.

FAO. (2020a). "COVID-19 and the risk to food supply chains: How to respond?" Rome. https://doi.org/10.4060/ca8388en.

FAO. (2020b). "Global food commodity prices drop further in April" [online] available: http://www.fao.org/news/story/en/item/1273914/icode/.

Freightos Baltic Index (FBX), (2021). Global Container Freight Index. https://fbx.freightos.com/.

Galanakis, C.M. (2020). "The Food Systems in the Era of the Coronavirus (COVID-19) Pandemic Crisis" Foods 9, no. 4: 523. https://doi.org/10.3390/foods9040523.

Govindan, K., Mina, H., Alavi, B. (2020). "A decision support system for demand management in healthcare supply chains considering the epidemic outbreaks: A case study of coronavirus disease 2019 (COVID-19)", Transportation Research Part E: Logistics and Transportation Review, Volume 138, https://doi.org/10.1016/j.tre.2020.101967.

HIS Markit (2020). "Impact of COVID-19 on the Chinese and global economy". https://ihsmarkit.com/researchanalysis/impact-of-covid19-on-the-chinese-and-globaleconomy.html.

HLPE. (2020). "Impacts of COVID-19 on food security and nutrition: developing effective policy responses to address the hunger and malnutrition pandemic". Rome. https://doi.org/10.4060/cb1000en.

Hummels, D., Ishii, J. \& Yi, K.M. (2001). “The nature and growth of vertical specialization in world trade”. Journal of International Economics, 54(1): 74-94. https://doi.org/10.1016/S00221996(00)00093-3.

ILO (2020). ILO Monitor: "COVID-19 and the world of work", ILO, https:/gisanddata.maps.arcgis.com/apps/opsdashboard/index.html\#/bda7594740fd40299423467b48e9ecf6.

Jewell, J. (2020). "Experts examine MH consequences of social distancing. Ment. Health Wkly”. P15.

Koopman, Robert, Zhi Wang, and Shang-Jin Wei. (2014). "Tracing Value-Added and Double Counting in Gross Exports.” American Economic Review, 104 (2): 459-94. https://DOI:10.1257/aer.104.2.459.

Lam, H., Remais, J.V., Fung, M.C., Xu, L.; Sun, S.S. (2013). "Food supply and food safety issues in China". Lancet, 381, 2044-2053. https://doi.org/10.1016/S0140-6736(13)60776-X.

Lopes de Sousa Jabbour, A.B., Chiappetta Jabbour, C.J., Hingley, M., eta 1., (2020), "Sustainability of supply chains in the wake of the coronavirus (COVID-19/SARS-CoV-2) pandemic: lessons and trends", Modern Supply Chain Research and Applications, Vol. 2 No. 3, pp. 117-122. https://doi.org/10.1108/MSCRA052020- 0011.

Man-Hung, T.C. (2018). The Belt and Road Initiative - the New Silk Road: A Research Agenda. J. Contemp. East Asia Stud. https://doi.org/10.1080/24761028.2019.1580407.

Meyer, M.A. (2020). "The role of resilience in food system studies in low- and middle-income countries". Global Food Security. 2020, 24, 100356. https://doi.org/10.1016/j.gfs.2020.100356.

MOA-Ministry of Agriculture of the People's Republic of China, (2020). http://english.agri.gov.cn/aboutmoa/message. (accessed on December 6, 2020).

Nenci, S. (2020). "Mapping global value chain (GVC) participation, positioning and vertical specialization in agriculture and food". Technical note for The State of Agricultural Commodity Markets (SOCO), FAO, Rome. https://doi.org/10.4060/cb0850en.

Nicola, M., Alsafi, Z., Sohrabi, C. et al. (2020). "The socio-economic implications of the coronavirus pandemic 
(COVID-19): A review". Int. J. Surg. 2020, 78, 184-190. https://doi.org/10.1016/j.ijsu.2020.04.018.

OECD. (2020). Covid-19 and global value chains: Policy options to build more resilient production networks.

OECD. (2020a). Interim Economic Assessment Coronavirus: The world economy at risk. [online] Available : http://www.oecd.org/.

OECD. (2020b). Trade Policy Implications of Global Value Chains, OECD Trade Policy Brief, [online] available: https://www.issuu.com/oecd.publishing/docs/.

OECD. (2020c). OECD Policy Responses to Coronavirus (COVID-19). Covid-19 and International Trade: Issues and actions. Accessed 29 December 2020.

Rodríguez-Pérez, C., Molina-Montes, E., Verardo, V., et al., (2020). Changes in Dietary Behaviours during the COVID-19 Outbreak Confinement in the Spanish COVIDiet Study. Nutrients 12, no. 6: 1730. https://doi.org/10.3390/nu12061730.

Sohrabi, C., Alsafi, Z., O’Neill, N., Khan, M., Kerwan, A., Al-Jabir, A., et al. (2020). World Health Organization declares global emergency: A review of the 2019 novel coronavirus $\quad$ (COVID-19). International Journal of Surgery, 76, 70-76. https://doi.org/10.1016/j.ijsu.2020.02.034.

Strange, R. (2020). The 2020 Covid-19 pandemic and global value chains. J. Ind. Bus. Econ. $\quad 47, \quad 455-465$ (2020). https://doi.org/10.1007/s40812-020-00162-X.

Torero M. (2020). Without food, there can be no exit from the pandemic. Countries must join forces to avert a global food crisis from COVID-19. Nature 580:588-589. https://doi.org/10.1038/d41586-020-01181-3.

UNACTAD. (2015). Tracing the Value added in Global Value Chains: Product-level case studies in China. UNCTAD/DITC/TNCD/2015/1.

UNCTAD. (2020). Coronavirus (COVID-19), News, Analysis, and Resources. Trade and Development Report. [online] Available: https://unctad.org/en/PublicationsLibrary/gdstdr2019.

WHO. (2020). WHO Director-General's opening remarks at the media briefing on COVID-19 - 11 March 2020. [Online] Available: https://www.who.int/director-general/speeches/detail/.

World Bank (2020). Global Economic Prospects: Lasting Scars of the COVID-19 Pandemic. June. Washington, DC: World Bank. https://doi.org/10.1596/978-1-4648-1553-9 ch3.

WTO Press Release 855. (2020a). Trade set to plunge as COVID-19 pandemic upends global economy [online] Available: https://www.wto.org/english/news_e/pres20_e/pr855 e.htm.

WTO. (2020). Trade shows signs of a rebound from COVID-19, recovery still uncertain. https://www.wto.org/english/news e/pres20 e/pr862 e.htm. Press release, 6 November 2020.

Zhan, S., Zhang, H., He, D. (2020). China's flexible overseas food strategy: Food trade and agricultural investment between Southeast Asia and China in 1990-2015. Globalizations, 15(5):702-721. https://DOI:10.080/14747731.2018.1491688.

Zhang, Y., Diao, X., Chen, K.Z., Robinson, S. and Fan, S. (2020), "Impact of COVID-19 on China's macroeconomy and agri-food system - an economy-wide multiplier model analysis", China Agricultural Economic Review, Vol. 12 No. 3, pp. 382-406. https://doi.org/10.1108/CAER-04-2020-006. 